\title{
В. В. Борщевський
}

\section{Детінізація оптової та роздрібної торгівлі регіонів України як чинник підвищення ефективності використання потенціалу їх розвитку}

\begin{abstract}
Досліджуються особливості поширення тіньової економіки у сфері оптової та роздрібної торгівлі регіонів України. На основі використання методу збитковості підприємств виявлено характер та особливості тінізації торговельної сфери в різних регіонах України. Встановлено, ияо найбільш підвладними тіньовим проиесам є торговельні підприємства у великих містах і прикордонних регіонах держави. Саме ціі регіони відіграють основну роль у розвитку оптової та роздрібної торгівлі в Україні. Одночасно в структурі їх економіки торгівля займає більш вагоме значення, ніж в інших регіонах. Окреслено основні тенденції у зміні обсягу тіньової економіки в торговельній сфері України та ї̈ регіонів. Порівняно з 2013 p. у 2017 р. у більшості регіонів держави спостерігалося зменшення обсягів тіньових операиій у секторі підприємств оптової та роздрібної торгівлі. Водночас ие супроводжувалося збільшенням кількості фізичних осіб-підприємиів, які здійснюють торговельну діяльність. Це стало підставою для висновку про перетікання частини тіньового ринку оптової та роздрібної торгівлі в регіонах України у сектор фізичних осіб-підприємиів. Саме такий спосіб ухиляння від сплати податків набув особливого поширення в Україні протягом останніх років. Як наслідок, обсяг тіньових операцій в оптовій та роздрібній торгівлі Украӥни сягнув близько 50\%, коливаючись у різних регіонах від 3540\% до 60\% і більше. Сформульовано пропозиції, спрямовані на детінізацію торговельної сфери, впровадження яких дозволить суттєво знизити обсяг тіньових операчій в оптовій та роздрібній торгівлі більшості регіонів Украӥни та підвищити на цій онові ефективність використання соціальноекономічного потенціалу їх розвитку. Зазначені пропозиції передбачають впровадження інституційних змін, спрямованих на обмеження можливості торговельних мереж використовувати фізичних осібпідприємців для ухиляння від сплати податків. Крім того, пропонується посилити вплив органів місцевого самоврядування на контроль за діяльністю господарюючих суб'єктів у сфері оптової та роздрібної торгівлі регіонів, зокрема завдяки зміні механізму справляння єдиного податку та податку на доходи фізичних осіб.
\end{abstract}

Ключові слова: оптова та роздрібна торгівля, тіньові операції, детінізація, регіональний розвиток, економічний потенціал.

Постановка проблеми. Однією з головних проблем, які сьогодні спричиняють уповільнення розвитку вітчизняної економіки, є високий рівень їі тінізації. Передусім це стосується поширення різних способів ухиляння від сплати податків, зокрема шляхом впровадження так званих «оптимізаційних» схем. Особливо підвладними тінізації є ті сфери економіки, які пов’язані зі швидким обігом товарів і можливістю одночасного використання різних організаційно-правових форм під час здійснення підприємницької діяльності, зокрема оптова та роздрібна торгівля.

Деструктивний вплив тінізації торговельної сфери по-різному відображається на економічному розвитку окремих територій. Найбільш відчутним він $є$ у тих регіонах, які через свої просторово-географічні чи культурно-історичні особливості відзначаються високим рівнем відкритості економіки та мають значний транзитний потенціал. Натомість там, де частка оптової та роздрібної торгівлі у створенні ВДВ є не надто вагомою, вплив тіньової економіки у торговельній сфері виявляється менш руйнівним для регіонального розвитку. Це актуалізує проблему дослідження особливостей функціонування оптової та роздрібної торгівлі в регіонах України, зокрема у контексті поширеності тіньових операцій у цій сфері та пошуку шляхів підвищення ефективності використання наявного потенціалу регіонального розвитку на основі її детінізації.

Аналіз останніх досліджень. Різні аспекти окресленої проблематики, зважаючи на їі актуальність та наукову значимість, досліджувалися багатьма

(С) В. В. Борщевський, 2020. 
вітчизняними вченими. Зокрема, свій внесок у вирішення проблем, пов'язаних 3 формуванням та поширенням тіньової економіки у торговельній сфері України та іiї окремих регіонів, зробили такі українські економісти, як Р. Августин, А. Базилюк, 3. Варналій, А. Вдовиченко, Б. Данилишин, Я. ЖКаліло, М. Заверуха, А. Зубрицький, О. Морицан, Г. Осадча, О. Пасхавер, Ю. Пічугіна, В. Ретунських, О. Рубцов, Д. Серебрянський, М. Флейчук, Т. Цвігун та ін.

Дослідженню особливостей розвитку оптової та роздрібної торгівлі в Україні та її регіонах присвячені наукові праці В. Апопія, Г. Богославець, Н. Власової, Н. Голошубової, В. Гросул, Т. Кузькіної, В. Лагутіна, І. Лазебної, Г. Лисак, Л. Лігоненко, А. Мазаракі, Д. Мардар, Н. Міценко, А. Носуліч, І. Сотник, О. Трубей та інших дослідників.

Водночас до цього часу залишається невирішеною низка проблем, пов'язаних 3 оцінюванням регіональних особливостей поширення тіньової економіки в оптовій та роздрібній торгівлі України та розробленням пропозицій, спрямованих на підвищення ефективності використання потенціалу торговельної сфери в економічному розвитку окремих регіонів нашої держави, зокрема на основі реалізації заходів з детінізації.

Мета статті - виявити характерні особливості та чинники поширення тіньової економіки в оптовій і роздрібній торгівлі регіонів України та сформулювати на цій основі пропозиції щодо пріоритетних напрямів підвищення ефективності використання економічного потенціалу регіонів на основі детінізації означеної сфери.

Основні результати дослідження. Розвиток торговельної сфери в Україні є невід'ємною ланкою становлення цивілізованих ринкових стосунків як на загальнодержавному, так і на регіональному рівні. Адже на пострадянському просторі торгівля традиційно є важливим елементом утвердження конкурентного механізму функціонування ринків. Навіть в умовах адміністративно-планової системи господарювання в торговельній сфері спостерігалися прояви конкуренції та елементи позапланових (квазіринкових) відносин. Однак в умовах жорсткого централізованого регулювання економіки вони здебільшого набували неофіційного характеру, виливаючись у спекуляцію, незаконний обіг дефіцитних товарів, торгівлю контрафактною та необлікованою продукцією тощо.

На жаль, багато з описаних явищ продовжилися і в умовах становлення ринкових відносин, еволюціонуючи та укорінюючись у різних формах тіньової економіки. Так, на пострадянському етапі економічного розвитку України набули поширення такі негативні явища, як торгівля контрабандними товарами, заниження митної вартості імпортованих товарів, ухиляння від сплати податків, іллегальна торгівля, узгоджена антиконкурентна поведінка торговельних компаній з метою завищення роздрібних цін тощо. Водночас збереглися, а подекуди і набули свого значного розвитку торгівля контрафактною та необлікованою продукцією, перепродаж товарів за спекулятивними цінами, торгівля некондиційними товарами тощо.

Означені проблеми зумовили цілу низку деструктивних явищ і тенденцій у вітчизняній економіці, проєктуючись на різні сфери господарської діяльності торговельних підприємств як на загальнодержавному, так i на регіональному рівні. Зокрема, дослідники відзначають, що, наприклад, контрабанда нерозривно пов'язана з корупцією в митних i правоохоронних органах, спричиняючи зниження ефективності державного регулювання економіки та посилення різних форм адміністративного тиску на бізнес, включно з практикою рейдерства. До того ж у прикордонних регіонах України контрабанда стає причиною суттєвих недонадходжень до місцевих бюджетів і перенасичення ринку дешевою та не завжди якісною продукцією імпортного виробництва (насамперед алкоголем, продовольчими товарами, виробами легкої промисловості, побутовою технікою, 
нафтопродуктами тощо), знижуючи тим самим конкурентоспроможність внутрішніх виробників [1, с. 30].

Разом з прямими збитками, які тіньова економіка завдає торговельній сфері, вона також містить у собі загрозу деструктивних «латентних впливів», серед яких першочергове значення дослідники відводять: скороченню внутрішніх інвестиційних ресурсів через проблеми з використанням коштів, набутих у тіньовий спосіб, та їх подальшим відтоком за кордон; зменшенню інтересу потенційних стратегічних інвесторів до українських підприємств, що значно гальмує процеси їх фінансового оздоровлення; деформації структури зайнятості; моральним наслідкам поширення тіньового обігу товарів і послуг, зокрема соціальному песимізму та деформації свідомості більшості учасників ринку, укоріненню різних форм нездорової конкуренції між ними [9, с. 254].

Для аналізу рівня та характерних особливостей поширення тіньової економіки в торговельній сфері України та їі регіонів можна використовувати декілька емпіричних методів. Так, згідно з наказом Мінекономіки від 18.02.2009 р. № 123 «Про затвердження Методичних рекомендацій розрахунку рівня тіньової економіки» доцільно застосовувати такі методи:

- «витрати населення - роздрібний товарооборот» (полягає у виявленні наявності перевищення споживчих грошових витрат населення на придбання товарів над загальним обсягом продажу населенню товарів усіма суб'єктами господарювання в легальному секторі економіки);

- фінансовий (полягає у визначенні тенденцій зміни пропорцій між вартістю товарів, робіт і послуг, використаних у процесі виробництва, та валовим доходом підприємств (господарських об'єднань), установ, організацій у країні загалом або в певному виді економічної діяльності);

- монетарний (полягає у визначенні тенденцій зміни співвідношення обсягу готівки та банківських депозитів у періоді, що аналізується, порівняно 3 базовим періодом, за який прийнято 1991 р.);

- «електричний» (полягає в порівнянні приросту внутрішнього споживання електроенергії з приростом ВВП);

- «збитковості підприємств» (полягає у визначенні граничних мінімального та максимального коефіцієнтів тіньової економіки як частки ВВП, у межах яких перебуває рівень тіньової економіки) [6].

Враховуючи практичну обмеженість можливості застосування методу «витрати населення - роздрібний товарооборот» та монетарного методу для аналізу рівня тіньової економіки в межах певного виду економічної діяльності, зокрема у сфері оптової та роздрібної торгівлі, а також беручи до уваги недостатню релевантність фінансового методу для оцінювання рівня тіньової економіки у торговельній сфері окремих регіонів, найбільш доцільним, на нашу думку, з погляду можливості ідентифікації рівня тіньової економіки в оптовій та роздрібній торгівлі регіонів України є метод збитковості підприємств.

В основі його застосування лежить припущення, що всі збиткові підприємства за офіційними статистичними даними фактично є прибутковими, а сам факт їх існування вважається завищенням обсягів тіньової економіки. Відтак рентабельність збиткових підприємств можна прирівняти до рентабельності прибуткових підприємств у періоді, що аналізується $\left(R_{3 t}=R_{\Pi t}\right)$.

Умовний прибуток збиткових підприємств у періоді, що аналізується $\left(M_{\text {Пзуt }}\right)$, розраховується за такою формулою:

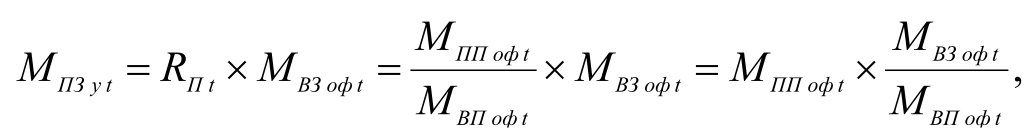

де: $M_{\text {взофt }}$-витрати збиткових підприємств у періоді, що аналізується, за офіційними статистичними даними, млн грн; 
$M_{\text {вПофt }}$-витрати прибуткових підприємств у періоді, що аналізується, за офіційними статистичними даними, млн грн;

$M_{\text {ппоф }}$-прибуток прибуткових підприємств у періоді, що аналізується, за офіційними статистичними даними, млн грн.

Співвідношення витрат збиткових і прибуткових підприємств вважається тотожним співвідношенню кількості таких підприємств:

$$
\frac{M_{B 3 \circ \phi t}}{M_{B \Pi \text { oकt }}}=\frac{l_{3 o \phi t}}{l_{\Pi \text { II } t}},
$$

де: $l_{\text {зофt }}$ - кількість збиткових підприємств у періоді, що аналізується, за офіційними статистичними даними, одиниць;

$l_{\text {Пофt }}$ - кількість прибуткових підприємств у періоді, що аналізується, за офіційними статистичними даними, одиниць.

Тоді граничний мінімальний коефіцієнт тіньової економіки $\left(K_{T \min t}\right)$ розраховують, враховуючи зазначені припущення, за такою формулою:

$$
K_{T \min t}=\frac{M_{T t}}{B B \Pi_{t}},
$$

де: $M_{T t}-$ тіньовий прибуток у періоді, що аналізується, млн грн;

$B B \Pi_{t}-$ обсяг ВВП у періоді, що аналізується, млн грн.

Наступним кроком є розрахунок тіньового прибутку в періоді, що аналізується $\left(M_{T t}\right)$, за такою формулою:

$$
M_{T t}=M_{\Pi 3 y t}+M_{\Pi 3 o \phi t}
$$

де: $M_{\text {пзут }}$-умовний прибуток збиткових підприємств у періоді, що аналізується, млн грн;

$M_{\text {пзофt }}$-частина валової доданої вартості продукції збиткових підприємств, що за офіційними статистичними даними є збитком збиткових підприємств, млн грн.

Граничний максимальний коефіцієнт тіньової економіки ( $K_{T \max t}$ ) обчислюють, враховуючи припущення, що всі прибуткові підприємства відображають у звітах лише невикривлені дані, а всі збиткові підприємства приховують весь обсяг валової доданої вартості виробленої ними продукції, а не тільки прибуток. У цьому разі граничний максимальний коефіцієнт тіньової економіки розраховується за такою формулою:

$$
K_{T \max t}=\frac{l_{3 o \phi t}}{l_{\Pi o \phi t}+l_{3 o \phi t}} .
$$

Застосувавши вказаний алгоритм розрахунку для визначення рівня тіньової економіки у сфері оптової та роздрібної торгівлі України в розрізі окремих регіонів, ми отримали результати, представлені в табл. 1.

Так, у 2017 р. найвищий рівень тіньової економіки спостерігався у торговельній сфері Донецької, Дніпропетровської, Кіровоградської, Київської та Сумської областей, а також у місті Києві. Водночас найнижчими відповідні показники виявилися в Луганській, Івано-Франківській, Тернопільській, Жћитомирській і Черкаській областях (табл. 1). 
Таблиця 1

Показники рівня тіньової економіки, розраховані за методом збитковості підприємств для сектору оптової та роздрібної торгівлі (з урахуванням підприємств з ремонту автотранспортних засобів і мотоциклів)

\begin{tabular}{|c|c|c|c|c|}
\hline \multirow[t]{2}{*}{ Регіон (область) } & \multicolumn{2}{|c|}{$\begin{array}{c}\text { Граничний мінімальний коефіцієнт } \\
\text { тіньової економіки, \% від ВРП }\end{array}$} & \multicolumn{2}{|c|}{$\begin{array}{c}\text { Граничний максимальний } \\
\text { коефіцієнт тіньової економіки, } \\
\% \text { від ВРП } \\
\end{array}$} \\
\hline & $2013 \mathrm{p}$. & $2017 \mathrm{p}$. & $2013 \mathrm{p}$. & 2017 p. \\
\hline Вінницька & 19,6 & 9,2 & 28,3 & 22,6 \\
\hline Волинська & 23,7 & 18,2 & 37,1 & 27,5 \\
\hline Дніпропетровська & 66,6 & 23,1 & 35,6 & 24,6 \\
\hline Донецька & 17,5 & 45,4 & 30,0 & 19,0 \\
\hline Житомирська & 9,9 & 5,7 & 31,5 & 22,9 \\
\hline Закарпатська & 11,8 & 8,4 & 29,1 & 24,2 \\
\hline Запорізька & 12,7 & 13,9 & 32,8 & 20,0 \\
\hline Івано-Франківська & 14,0 & 9,1 & 25,3 & 18,8 \\
\hline Київська & 21,8 & 27,9 & 28,0 & 20,8 \\
\hline Кіровоградська & 15,1 & 28,6 & 32,1 & 20,1 \\
\hline Луганська & 12,9 & 3,9 & 31,9 & 19,4 \\
\hline Львівська & 12,1 & 8,8 & 33,3 & 23,6 \\
\hline Миколаївська & 8,7 & 16,0 & 30,3 & 23,5 \\
\hline Одеська & 14,9 & 15,9 & 32,7 & 22,5 \\
\hline Полтавська & 18,3 & 7,9 & 29,9 & 23,5 \\
\hline Рівненська & 20,0 & 9,3 & 35,7 & 26,6 \\
\hline Сумська & 14,3 & 26,8 & 34,9 & 26,6 \\
\hline Тернопільська & 62,1 & 7,7 & 33,8 & 19,4 \\
\hline Харківська & 19,5 & 16,1 & 34,4 & 26,2 \\
\hline Херсонська & 17,1 & 6,1 & 28,9 & 22,1 \\
\hline Хмельницька & 26,3 & 11,8 & 29,5 & 18,9 \\
\hline Черкаська & 10,8 & 7,0 & 28,9 & 19,8 \\
\hline Чернівецька & 19,1 & 6,3 & 38,3 & 29,7 \\
\hline Чернігівська & 14,8 & 6,9 & 30,0 & 23,2 \\
\hline місто Київ & 39,6 & 24,1 & 35,5 & 29,4 \\
\hline В середньому по Україні & 20,9 & 31,9 & 14,6 & 23,0 \\
\hline
\end{tabular}

Джерело: розраховано за даними [7, с. 347-349], [8, с. 112-114] та інформацією головних управлінь статистики у відповідних регіонах.

Порівняно з 2013 р. найкращою динаміка зниження рівня тіньової економіки протягом 2013-2017 pр. мала місце в оптовій і роздрібній торгівлі Тернопільської та Дніпропетровської областей. Доволі стрімкими темпами зниження обсягу тіньових операцій у торговельній сфері відбувалося також у Луганській та Чернівецькій областях і місті Києві. Натомість у Миколаївській, Кіровоградській, Сумській та особливо Донецькій областях відбулося зростання рівня тіньової економіки у досліджуваному секторі на тлі його загального зниження в Україні. Вказане зростання зумовлене насамперед істотним збільшенням граничного мінімального коефіцієнта тіньової економіки, в основі розрахунку якого лежить показник величини збитків підприємств оптової та роздрібної торгівлі (тоді як граничний максимальний коефіцієнт тіньової економіки розраховується на базі загальної кількості збиткових підприємств). В окремих областях аномально високий рівень збитковості підприємств оптової та роздрібної торгівлі навіть призвів до того, що граничний мінімальний коефіцієнт тіньової економіки там виявився вищим за граничний максимальний.

Цікавим з погляду аналізування тенденцій поширення тіньової економіки в торговельній сфері України та їі регіонів є оцінювання відповідних показників, 
ураховуючи вагомість кожного регіону в розвитку оптової та роздрібної торгівлі нашої держави загалом. До регіонів, які мають найбільшу частку в Україні за цим показником, належать: м. Київ, а також Дніпропетровська, Київська, Львівська, Одеська та Харківська області. Сумарно на них припадало $62 \%$ внеску оптової та роздрібної торгівлі у валову додану вартість усіх регіонів України у 2013 р. (без урахування АР Крим і міста Севастополя) та 71,3\% у 2017 р. (табл. 2).

Таблиця 2

Валова додана вартість в оптовій та роздрібній торгівлі регіонів України (з урахуванням послуг 3 ремонту автотранспортних засобів і мотоциклів) (у фактичних цінах)

\begin{tabular}{|c|c|c|c|c|}
\hline \multirow{2}{*}{ Регіон (область) } & \multicolumn{2}{|c|}{2013 p. } & \multicolumn{2}{|c|}{$2017 \mathrm{p}$. } \\
\hline & млн грн & $\%$ & млн грн & $\%$ \\
\hline Вінницька & 3384,0 & 1,6 & 6807,0 & 1,7 \\
\hline Волинська & 3035,0 & 1,4 & 11322,0 & 2,8 \\
\hline Дніпропетровська & 16661,0 & 7,9 & 28666,0 & 7,0 \\
\hline Донецька & 23047,0 & 10,9 & 10313,0 & 2,5 \\
\hline Житомирська & 2497,0 & 1,2 & 5667,0 & 1,4 \\
\hline Закарпатська & 3153,0 & 1,5 & 4751,0 & 1,2 \\
\hline Запорізька & 5492,0 & 2,6 & 10778,0 & 2,6 \\
\hline Івано-Франківська & 4465,0 & 2,1 & 6395,0 & 1,6 \\
\hline Київська & 12604,0 & 5,9 & 21540,0 & 5,3 \\
\hline Кіровоградська & 2662,0 & 1,3 & 4758,0 & 1,2 \\
\hline Луганська & 4953,0 & 2,3 & 1735,0 & 0,4 \\
\hline Львівська & 9527,0 & 4,5 & 19929,0 & 4,9 \\
\hline Миколаївська & 3678,0 & 1,7 & 7369,0 & 1,8 \\
\hline Одеська & 9620,0 & 4,5 & 18951,0 & 4,6 \\
\hline Полтавська & 4075,0 & 1,9 & 8685,0 & 2,1 \\
\hline Рівненська & 2273,0 & 1,1 & 4908,0 & 1,2 \\
\hline Сумська & 3504,0 & 1,7 & 4671,0 & 1,1 \\
\hline Тернопільська & 2123,0 & 1,0 & 3763,0 & 0,9 \\
\hline Харківська & 10559,0 & 5,0 & 18741,0 & 4,6 \\
\hline Херсонська & 2202,0 & 1,0 & 4328,0 & 1,1 \\
\hline Хмельницька & 2439,0 & 1,1 & 5635,0 & 1,4 \\
\hline Черкаська & 3521,0 & 1,7 & 8396,0 & 2,0 \\
\hline Чернівецька & 1578,0 & 0,7 & 3378,0 & 0,8 \\
\hline Чернігівська & 2445,0 & 1,2 & 4289,0 & 1,0 \\
\hline місто Київ & 72593,0 & 34,2 & 184219,0 & 44,9 \\
\hline Разом & 212090,0 & 100,0 & 409994,0 & 100,0 \\
\hline
\end{tabular}

Джерело: розраховано за даними [2, с. 61].

Аналізуючи рівень тіньової економіки в оптовій та роздрібній торгівлі зазначених шести регіонів, спостерігаємо його стабільне переважання порівняно із середнім значенням в Україні (майже на $20 \%$ ). Це означає, що в перерахунку на абсолютні цифри обсяг тіньового ВДВ, який генерується в торговельному секторі України, є більшим за наведені розрахункові показники (приблизно на 7-10\%), встановлені на базі середніх даних для всіх регіонів нашої держави, і коливався у 2013 р. в межах $33-35 \%$, а у 2017 р. - в межах $24-25 \%$.

До того ж додаткове зростання величини тіньових операцій, яке не враховане в застосованій методиці оцінювання рівня тіньової економіки у сфері оптової та роздрібної торгівлі, може мати місце через наявність усталеної практики «оптимізації податків» завдяки використанню великими торговельними мережами механізму «розпорошення бізнесу» за участю фізичних осіб-підприємців.

Так, експерти відзначають, що внаслідок існуючих схем оптимізації податків через ФОП і псевдопідприємців, зокрема через їх активну участь в активізації 
«сірого імпорту», Україна щорічно втрачає до 100 млрд грн (до 25\% валової доданої вартості, створеної у сфері оптової та роздрібної торгівлі). Ці кошти вимиваються або повністю «в чорну» - коли товари реалізуються фізичними особами, які не сплачують взагалі ніяких податків (продаж з рук, нелегальні базари, деякі інтернет-магазини тощо), або ж у «квазілегальний» спосіб - коли товари реалізують ФОП, занижуючи свої обороти, сплачуючи податки частково (офлайн - та онлайн-магазини), чи коли фірми-одноденки оформлюють майже справжні документи на нелегально ввезений товар, а далі товар реалізується офіційними каналами. При цьому найбільш «тінізованим», на думку експертів, залишається продаж ювелірних виробів (понад 80\% усієї реалізації), одягу та взуття (близько 40\% тіньового ринку), паливо-мастильних матеріалів (40\% у тіні), продовольчих товарів (понад $30 \%$ іллегального товарообігу, хоча для окремих груп продовольчих товарів він перевищує 50\%) [3].

Як уже зазначалося, різні схеми тінізації торговельної сфери поширені переважно у великих містах України і тих регіонах, центрами яких вони є, а також у прикордонних регіонах нашої держави. Адже саме тут спостерігається найбільш активний товарообіг, зумовлений як високим споживчим попитом населення, так і значним обсягом імпорту товарів. Одночасно у таких регіонах оптова та роздрібна торгівля займає достатньо вагоме місце у структурі економіки. Передусім це стосується міста Києва, а також Київської, Львівської, Одеської, Волинської, Чернівецької та Закарпатської областей (табл. 3).

Таблиця 3

Оптова та роздрібна торгівля у ВДВ та випуску продукції регіонів України

(з урахуванням послуг з ремонту автотранспортних засобів і мотоциклів)

\begin{tabular}{|l|c|c|c|c|}
\hline \multirow{2}{*}{ Регіон (область) } & \multicolumn{2}{|c|}{$\begin{array}{c}\text { Частка випуску в регіоні } \\
\text { (у фактичних цінах), }\end{array}$} & \multicolumn{2}{c|}{ Частка у ВДВ регіону, \% } \\
\cline { 2 - 5 } & $2013 \mathrm{p}$. & $2017 \mathrm{p}$. & $2013 \mathrm{p}$. & $2017 \mathrm{p}$. \\
\hline Вінницька & 7,8 & 6,2 & 10,3 & 8,9 \\
\hline Волинська & 12,7 & 21,1 & 16,1 & 25,5 \\
\hline Дніпропетровська & 9,5 & 8,5 & 12,9 & 11,4 \\
\hline Донецька & 10,8 & 5,2 & 16,8 & 8,0 \\
\hline Житомирська & 8,9 & 8,7 & 10,7 & 10,7 \\
\hline Закарпатська & 12,7 & 10,6 & 15,9 & 12,4 \\
\hline Запорізька & 7,8 & 6,8 & 12,0 & 10,7 \\
\hline Івано-Франківська & 11,0 & 8,5 & 14,9 & 11,6 \\
\hline Київська & 16,4 & 13,1 & 20,9 & 16,3 \\
\hline Кіровоградська & 9,0 & 8,4 & 11,9 & 10,4 \\
\hline Луганська & 8,9 & 5,3 & 10,6 & 6,7 \\
\hline Львівська & 13,4 & 12,8 & 16,7 & 15,5 \\
\hline Миколаївська & 10,3 & 10,3 & 12,9 & 12,5 \\
\hline Одеська & 12,6 & 11,4 & 15,4 & 14,6 \\
\hline Полтавська & 5,6 & 5,4 & 8,1 & 6,9 \\
\hline Рівненська & 8,8 & 9,1 & 11,4 & 11,6 \\
\hline Сумська & 11,0 & 8,2 & 14,6 & 9,7 \\
\hline Тернопільська & 10,2 & 8,5 & 12,8 & 10,6 \\
\hline Харківська & 10,9 & 9,3 & 14,0 & 11,7 \\
\hline Херсонська & 10,1 & 9,7 & 11,6 & 10,5 \\
\hline Хмельницька & 8,1 & 8,5 & 10,2 & 10,3 \\
\hline Черкаська & 8,2 & 9,9 & 12,1 & 13,9 \\
\hline Чернівецька & 11,6 & 12,6 & 12,2 & 13,1 \\
\hline Чернігівська & 9,4 & 7,3 & 11,1 & 8,8 \\
\hline місто Київ & 22,9 & 27,4 & 26,3 & 30,3 \\
\hline Всього в Україні & 12,8 & 13,2 & 16,7 & 16,3 \\
\hline
\end{tabular}

Джерело: розраховано за даними [2, с. 80, 104, 110, 134]. 
Як видно з наведеної таблиці, регіони, де частка торгівлі займає найбільш вагоме значення у валовій доданій вартості та у випуску продукції, переважно збігаються з переліком тих регіонів, які відзначаються найбільшою питомою вагою за показником оптової та роздрібної торгівлі в України загалом.

Це ж саме стосується і регіонів, де вказана частка є найнижчою, зокрема Вінницької, Луганської, Полтавської, Хмельницької та Чернігівської областей, які одночасно належать до тих регіонів, що в загальному розвитку оптової та роздрібної торгівлі України відіграють доволі невелику роль. Проте за показником частки тіньової економіки у торговельній сфері вони не є відвертими аутсайдерами, що дає підставу для висновку про відсутність визначального впливу торговельних підприємств на формування тіньового товарообігу в регіоні. Значною мірою це зумовлено переважанням фізичних осіб-підприємців у торговельній сфері більшості регіонів нашої держави.

Наприклад, за даними Державної служби статистики України, протягом 2013-2017 pp. частка ФОП у сфері оптової та роздрібної торгівлі порівняно з їх питомою вагою в усіх видах економічної діяльності в Україні була приблизно на $10 \%$ вищою, відзначаючись при цьому тенденцією до зростання. Так, якщо у 2013 р. ФОП становили 87,6\% усіх суб'єктів господарювання у сфері оптової та роздрібної торгівлі України (порівняно з $77,2 \%$ в усіх видах економічної діяльності нашої держави), то вже у 2017 р. їх частка зросла до 89,3\% (на тлі $81,3 \%$ загальноукраїнського показника) (табл. 4).

Таблиця 4

Кількість суб’єктів господарювання в оптовій та роздрібній торгівлі України

(з урахуванням підприємств з ремонту автотранспортних засобів і мотоциклів)

\begin{tabular}{|l|c|c|c|c|}
\hline \multicolumn{1}{|c|}{ Показники } & \multicolumn{2}{|c|}{2013 p. } & \multicolumn{2}{c|}{2017 p. } \\
\cline { 2 - 5 } & одиниць & $\%$ & одиниць & $\%$ \\
\hline $\begin{array}{l}\text { Кількість суб'єктів господарювання в оптовій та } \\
\text { роздрібній торгівлі; ремонті автотранспортних засобів } \\
\text { i мотоциклів, 3 них: }\end{array}$ & 890658 & 100,0 & 837797 & 100,0 \\
\hline - підприємства & 110414 & 12,4 & 89538 & 10,7 \\
\hline - фізичні особи-підприємці & 780244 & 87,6 & 748259 & 89,3 \\
\hline $\begin{array}{l}\text { Кількість суб’єктів господарювання в усіх видах } \\
\text { економічної діяльності в Україні, з них: }\end{array}$ & 1722251 & 100,0 & 1805144 & 100,0 \\
\hline - підприємства & 393508 & 22,8 & 338341 & 18,7 \\
\hline - фізичні особи-підприємці & 1328743 & 77,2 & 1466803 & 81,3 \\
\hline
\end{tabular}

Джерело: розраховано за даними [4, с. 19].

Беручи до уваги зазначене, можна висловити припущення, що загальний рівень тіньового товарообігу в торговельній сфері України сьогодні значно перевищує тих $24-25 \%$, які було виявлено за допомогою методу збитковості підприємств. Адже попри незначне скорочення обсягу тіньових операцій у секторі торговельних підприємств нашої держави з 2013 р. до 2017 р., значна частка тіньових операцій, найімовірніше, була переміщена у сферу фізичних осіб-підприємців.

Зважаючи на зазначене, основним напрямом зниження рівня поширеності тіньової економіки в торговельній сфері України, а відтак і засобом підвищення ефективності використання іiї економічного потенціалу на сучасному етапі $\epsilon$ впровадження сучасних інструментів запобігання ухилянню торговельних мереж від сплати податків і митних платежів за допомогою використання інституту фізичних осіб-підприємців (ФОП).

Для цього слід здійснити низку інституційних змін, спрямованих на наближення вітчизняних ФОП до тієї економічної сутності, яка є визначальною для них як для підприємницького інституту в усьому цивілізованому світі. Адже за своєю природою ФОП не призначений для ведення системного бізнесу, не кажучи вже 
про участь в оптовій торгівлі та гуртовому імпорті товарів. Він виник як спосіб легалізації самозайнятих осіб для надання їм можливості започатковувати власну справу без ведення складної бухгалтерської звітності. Держава отримувала від цього не стільки податкові надходження, скільки зниження рівня безробіття та соціального навантаження на бюджет, а також імпульс для розвитку підприємництва.

Отже, першим кроком для зменшення тіньового сектору в оптовій та роздрібній торгівлі більшості українських регіонів має стати унормування статусу фізичноїособи підприємця в торговельній сфері. Це означає, що таким підприємцям має бути заборонено працювати на спільних торговельних майданчиках під егідою великих торговельних центрів чи супермаркетів. Крім того, для ФОП слід суттєво обмежити можливість участі в експортно-імпортних операціях. I, звичайно ж, все це має підкріплюватися адекватною системою державного контролю та моніторингу їх діяльності.

Другим напрямом детінізації торговельної сфери на регіональному рівні має стати надання права органам місцевого самоврядування адмініструвати місцеві податки та збори, які є джерелом наповнення їхніх бюджетів. Передусім це стосується єдиного податку з ФОП, задіяних у сфері роздрібної торгівлі в невеликих містах і в сільській місцевості. У цьому разі в місцевої влади виникне дієвий стимул посили контроль за діяльністю невеличких магазинів, а також роздрібних ринків, що суттєво обмежить можливості продажу ними необлікованої чи контрафактної продукції, не кажучи вже про ухиляння від сплати податків.

Дієвість такого засобу може бути посилена зміною механізму справляння податку на доходи фізичних осіб. Замість існуючої практики зарахування цього податку до місцевого бюджету за місцем реєстрації торговельного підприємства, його доцільно спрямовувати до місцевого бюджету за місцем реєстрації працівника. Це може суттєво зменшити тіньову складову в оптовій та роздрібній торгівлі великих міст, які сьогодні є лідерами за рівнем тінізації торговельної сфери. Одночасно відбудеться покращення контролю за якістю справляння цього податку, особливо на рівні невеликих територіальних громад, де, як правило, зареєстрована переважна кількість найманих працівників великих торговельних мереж і гуртових та роздрібних ринків.

Важливу роль у детінізації торговельної сфери в тих регіонах, які є лідерами за часткою тіньового товарообігу в Україні, може відіграти також діджиталізація системи фінансових розрахунків і процедур адміністрування бізнесу. Проте вона передбачає збільшення відповідних фінансових витрат як з державного, так і з місцевих бюджетів. А це актуалізує проблему якнайшвидшого завершення розпочатої в Україні адміністративно-територіальної реформи, яка має супроводжуватися поглибленням фінансово-бюджетної децентралізації, що в кінцевому підсумку дозволить забезпечити належний рівень фінансової спроможності місцевих громад і сприятиме підвищенню ефективності використання бюджетних ресурсів окремих регіонів та нарощуванню їх економічного потенціалу.

Висновки. Оптова та роздрібна торгівля в регіонах України має значний потенціал розвитку. Ефективність його використання великою мірою залежить від результативності заходів з детінізації торговельної сфери. Найбільш відчутним цей потенціал є в тих регіонах, де частка тіньових операцій у структурі валової доданої вартості, створюваної торговельними підприємствами, є найвищою. Передусім це стосується великих міст і прикордонних територій нашої держави.

Розрахунок обсягу тіньової економіки у торговельній сфері українських регіонів за методом збитковості підприємств засвідчив, що частка тіньових операцій у валовій доданій вартості, створюваній підприємствами оптової та роздрібної торгівлі в Україні, коливається в межах 15-25\%, відзначаючись тенденцією до зниження у 2017 р. порівняно з 2013 р. Водночас у торговельній сфері усіх без винятку регіонів нашої держави спостерігається істотне переважання фізичних 
осіб-підприємців, частка яких сьогодні наближається до $90 \%$ і має тенденцію до збільшення. За експертними оцінками, через цей сектор, разом із сектором «чорної торгівлі», з української економіки щорічно вимивається «в тінь» значний обсяг фінансових ресурсів, загальна сума яких наближається до 100 млрд грн, що становить близько $25 \%$ валової доданої вартості, створюваної підприємствами оптової та роздрібної торгівлі, а частка тіньового ринку оптової та роздрібної торгівлі в Україні сягає близько $50 \%$.

Для зменшення тіньового сегмента в торговельній сфері українських регіонів і нарощування на цій основі ефективності використання потенціалу їх соціальноекономічного розвитку доцільно запровадити низку інституційних заходів, спрямованих на обмеження можливостей торговельних мереж використовувати фізичних осіб-підприємців задля ухиляння від сплати податків. Крім того, доцільно підвищити ефективність контролю за діяльністю закладів оптової та роздрібної торгівлі, а також змінити механізм справляння єдиного податку та податку на доходи фізичних осіб задля посилення впливу органів місцевого самоврядування за їх надходженням та підвищення рівня їх фінансової спроможності.

Подальші дослідження у цьому напрямі слід спрямувати на виявлення інституційних бар’єрів на шляху детінізації оптової та роздрібної торгівлі в окремих регіонах України та на розроблення пропозицій щодо підвищення ефективності використання їх соціально-економічного потенціалу на основі детінізації торговельної сфери.

\section{Список використаних джерел}

1. Августин Р. Наслідки експансії глобальної тіньової економіки в систему вітчизняного внутрішньоекономічного розвитку. Вісник Дніпропетровського університету. Серія «Економіка». 2014. Вип. 8(4). С. 27-34.

2. Валовий регіональний продукт у 2017 році: стат. зб. К.: Державна служба статистики України, 2019. $158 \mathrm{c}$.

3. Гетман О. Як мінімізувати схеми по ухилянню від сплати податків при роздрібній торгівлі?. Business Coalition: сайт. 2019. URL: https://bc-ua.org/novini/yak-minimizuvati-sxemi-po-uxilyannyu-vid-splatipodatkiv-pri-rozdribnij-torgivli

4. Діяльність суб'єктів господарювання 2018: стат. зб. К.: Державна служба статистики України, 2019. $164 \mathrm{c.}$

5. Загальні тенденції тіньової економіки в Україні у 2018 р. Міністерство розвитку економіки, торгівлі та сільського господарства Украӥни: сайт. 15.07.2019 p. URL: https://www.me.gov.ua/Documents/ List?lang=uk-UA\&id=e384c5a7-6533-4ab6-b56f-50e5243eb15a\&tag=TendentsiiTinovoiEkonomiki

6. Про затвердження Методичних рекомендацій розрахунку рівня тіньової економіки: наказ Мінекономіки від 18.02.2009 р. № 123. Міністерство розвитку економіки, торгівлі та сільського господарства Украӥни: сайт. URL: https:/www.me.gov.ua/LegislativeActs/Detail?lang-uk-UA\&id=4bb297a0-c900-404f-8c6f5f76f18b1503

7. Регіони України 2014. Ч. ІІ: стат. зб. К.: Державна служба статистики України, 2014. 732 с.

8. Регіони України 2019. Ч. ІІ: стат. зб. К.: Державна служба статистики України, 2019. 656 с.

9. Цвігун Т., Нечипорук О. Тінізація економіки: причини та особливості впливу на економічний розвиток. Економіка та управління національним господарством. 2018. Вип. 19. С. 251-254.

\section{References}

1. Avhustyn, R. (2014). Naslidky ekspansiyi hlobal'noyi tinovoi ekonomiky v systemu vitchyznyanoho vnutrishn'oekonomichnoho rozvytku [Consequences of the global shadow economy expansion into the system of domestic internal economic development]. Visnyk Dnipropetrovs 'koho universytetu. Seriya «Ekonomika»Bulletin of Dnipropetrovsk University. Series: Economics, 8(4), 27-34. [in Ukrainian].

2. Valovyy rehional'nyy produkt u 2017 rotsi [Gross regional product in 2017]: Statistical publication (2019). K.: State Statistics Service of Ukraine. [in Ukrainian].

3. Hetman, O. (2019). Yak minimizuvaty skhemy po ukhylyannyu vid splaty podatkiv pry rozdribniy torhivli? [How to minimize retail tax evasion schemes?] (2019). Business Coalition: Website. Retrieved from https:// bc-ua.org/novini/yak-minimizuvati-sxemi-po-uxilyannyu-vid-splati-podatkiv-pri-rozdribnij-torgivli [in Ukrainian].

4. Diyal'nist'sub"yektiv hospodaryuvannya 2018 [Business entities activity 2018]: Statistical publication (2019). K.: State Statistics Service of Ukraine. [in Ukrainian]. 
5. Zahal'ni tendentsiyi tin'ovoyi ekonomiky v Ukrayini u 2018 r. [General trends of the shadow economy in Ukraine in 2018] (2019). Ministry of Economic Development, Trade and Agriculture of Ukraine: Website. Retrieved from https:/www.me.gov.ua/Documents/List?lang=uk-UA\&id=e384c5a7-6533-4ab6-b56f-50e5243eb1 5a\&tag=TendentsiiTinovoiEkonomiki [in Ukrainian].

6. Pro zatverdzhennya Metodychnykh rekomendatsiy rozrakhunku rivnya tin'ovoyi ekonomiky [On approval of Methodological recommendations for the calculation of the shadow economy level] (2009). Order of the Ministry of Economy of Ukraine, adopted on 2009, Feb 18, 123. Ministry of Economic Development, Trade and Agriculture of Ukraine: Website. Retrieved from https:/www.me.gov.ua/LegislativeActs/Detail?lang-ukUA\&id=4bb297a0-c900-404f-8c6f-5f76f18b1503 [in Ukrainian].

7. Rehiony Ukrainy 2014. Part II. [Regions of Ukraine 2014. P. II]: Statistical publication (2014). K.: State Statistics Service of Ukraine. [in Ukrainian].

8. Rehiony Ukrainy 2019. Part II [Regions of Ukraine 2019. P. II]: Statistical publication (2019). K.: State Statistics Service of Ukraine. [in Ukrainian].

9. Tsvihun, T., \& Nechyporuk, O. (2018). Tinizatsiya ekonomiky: prychyny ta osoblyvosti vplyvu na ekonomichnyy rozvytok [Shadowing the economy: causes and features of influence on economic development]. Ekonomika ta upravlinnya natsional'nym hospodarstvom - National economy management and economics, 19, 251-254. [in Ukrainian].

Borshchevskyy V. V. De-shadowing of the wholesale and retail trade in the regions of Ukraine as a factor of increasing the efficiency of using their development potential.

The paper examines the peculiarities of the spread of the shadow economy in the sphere of wholesale and retail trade in the regions of Ukraine. The nature and features of the trade sphere shadowing in different regions of Ukraine are revealed. The trade enterprises in large cities and near-border regions are established to be the most subject to the shadow processes. These regions play a main role in the development of wholesale and retail trade in Ukraine. At the same time, trade is more important in the structure of their economy compared to other regions. The main tendencies of the change of shadow economy volumes in the trade sphere of Ukraine and its regions are outlined. In 2017 compared to 2013, the volumes of shadow operations in the sector of wholesale and retail trade reduced in the prevailing number of Ukraine's regions. However, it was accompanied by an increase in the number of individual entrepreneurs in trading activities. This was the cause for a conclusion about the transition of the part of the shadow market in wholesale and retail trade in the regions of Ukraine into the sector of individual entrepreneurs. This manner of tax evasion has become especially widespread in Ukraine during recent years. As a result, the volume of shadow operations in the wholesale and retail trade in Ukraine has reached about 50\%, ranging from 35-40\% to 60\% and more in different regions. Proposals aimed at the de-shadowing of the trade sector of Ukraine are formulated. Their implementation will allow to reduce the volume of shadow operations in the wholesale and retail trade of most regions of Ukraine and to increase the efficiency of using the socio-economic potential of their development. These proposals are intended to introduce institutional changes aimed at limiting the ability of retailers to use individual entrepreneurs for tax evasion. In addition, strengthening the influence of local self-government bodies on control of the economic entities' activity in the sphere of wholesale and retail trade in the regions is suggested.

Keywords: wholesale and retail trade, shadow operations, shadowing, regional development, economic potential.

Борщевський Віктор Валентинович - доктор економічних наук, доцент, провідний науковий співробітник відділу просторового розвитку ДУ «Інститут регіональних досліджень ілені М. I. Долішнього НАН України» (e-mail: borshchevsky@ukr.net, ORCID ID: https://orcid.org/0000-00021868-4434).

Borshchevskyy Viktor Valentynovych - Dr. Sci. (Econ.), Assoc. Prof., Leading Researcher of the Department of spatial development of the Dolishniy Institute of Regional Research of NAS of Ukraine.

Стаття написана в межах виконання наукової теми «Детінізація та використання потенціалу сектору комерційних послуг у забезпеченні соціально-економічного зростання регіонів України».

Надійшло 08.02.2020 p. 